

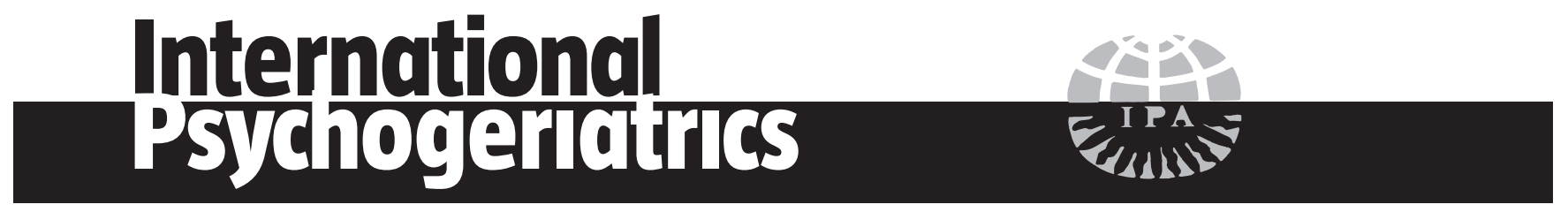

\section{Editorial Panel}

EDITOR-IN-CHIEF

Nicola T. Lautenschlager

Melbourne, Australia

DEPUTY EDITORS

Christina Bryant

Melbourne, Australia

Kostas Lyketsos

Baltimore, MD, USA

John O'Brien

Cambridge, UK

Craig Ritchie

London, UK

Guk-Hee Suh

Seoul, South Korea

ASSOCIATE EDITORS

Osvaldo Almeida

Perth, Australia

Olusegun Baiyewu

Ibadan, Nigeria

Susan Benbow

Wolverhampton, UK

Henry Brodaty

Sydney, Australia

Alistair Burns

Manchester, UK

Helen Chiu

Hong Kong, China

Jiska Cohen-Mansfield

Tel Aviv, Israel

Martin Cole

Montreal, Canada

Claudia Cooper

London, UK

George Demakis

Charlotte, NC, USA

Colleen Doyle

Melbourne, Australia

Leon Flicker

Perth, Australia

Mary Ganguli

Pittsburgh, PA, USA

Serge Gauthier

Montreal, Canada

Yonas Geda

Scottsdale, AZ, USA

Meredith Gresham

Sydney, Australia

Martin Haupt

Düsseldorf, Germany

Nathan Herrmann

Toronto, Canada

Akira Homma

Tokyo, fapan

K. S. Jacob

Vellore, India

Helen Kales

Ann Arbor, MI, USA

Rob Kok

The Hague, The Netherlands
Linda Lam

Hong Kong, China

João Carlos Barbosa Machado

Belo Horizonte, Brazil

Raimundo Mateos

Santiago de Compostela, Spain

Peter Rabins

Baltimore, MD, USA

Paul Rosenberg

Baltimore, MD, USA

Ajit Shah

London, UK

Gary Small

Los Angeles, CA, USA

Sergio Starkstein

Perth, Australia

David Steffens

Durham, NC, USA

Greg Swanwick

Dublin, Ireland

Johannes Wancata

Vienna, Austria

MANAGING EDITOR

Susan M. Oster

Northfield, IL, USA

STATISTICAL ADVISORS

Lucy Busija

Melbourne, Australia

(Joyce) H. Chung-Chou Chang

Pittsburgh, PA, USA

Hiroko H. Dodge

Portland, OR, USA

Theodore Malmstrom

St. Louis, MO, USA

BOOK REVIEW EDITOR

Michael Philpot

London, UK

FOUNDER EDITOR

Gene Cohen

Deceased

EDITOR EMERITUS

Robin Eastwood

Bere Ferrers, UK

PAST EDITORS

David Ames

Manfred Bergener

Gene Cohen

Robin Eastwood

Sanford Finkel

Kazuo Hasegawa

Akira Homma

ASSISTANT TO THE EDITOR-IN-CHIEF

Joan Mould

Melbourne, Australia
Subscriptions

International Psychogeriatrics (ISSN 1041-6102) is published monthly. The annual subscription price (excluding VAT), including delivery by air where appropriate, plus electronic access for subscribers of Volume 25 is $£ 632$ (US $\$ 1169$ in the USA, Canada and Mexico) for institutions; $£ 286$ (US $\$ 529$ in the USA, Canada and Mexico) for individuals ordering direct from the publisher and certifying that the journal is for their personal use. Single parts are $£ 79$ (US $\$ 151$ in the USA, Canada and Mexico) plus postage. The electronic only price and print only price available to institutional subscribers is $£ 481$ and $£ 632$ (US $\$ 889$ and $\$ 1169$ in the USA, Canada and Mexico), respectively. Orders, which must be accompanied by payment, may be sent to a bookseller, subscription agent or to the publisher: Cambridge University Press, The Edinburgh Building, Shaftesbury Road, Cambridge CB2 8RU, UK; or in the USA, Canada and Mexico: Cambridge University Press, Journals Fulfillment Department, 100 Brook Hill Drive, West Nyack, New York 10994-2133. EU subscribers (outside the UK) who are not registered for VAT should add VAT at their country's rate. VAT registered subscribers should provide their VAT registration number. Japanese prices for institutions are available from: Kinokuniya Company Ltd, PO Box 55, Chitose, Tokyo 156, Japan. Periodicals postage paid at New York, NY, and at additional mailing offices. POSTMASTER: send address changes in USA, Canada and Mexico to: International Psychogeriatrics, Cambridge University Press, 100 Brook Hill Drive, West Nyack, New York 10994-2133. Claims for missing issues should be made immediately on receipt of the subsequent issue.

\section{Internet access}

This journal is included in the Cambridge Journals Online service which can be found at journals.cambridge.org/ipg. For further information on other Press titles go to http//www.cambridge.org.

\section{Abstracts}

International Psychogeriatrics is abstracted and indexed in Abstracts in Social Gerontology; Current Literature on Aging; AgeLine; Combined Health Information Database (CHID); Cumulative Index to Nursing \& Allied Health Literature (CINAHL); Current Contents/Social and Behavioral Sciences; EMBASE/Excerpta Medica; e-psyche; Index Medicus/ MEDLINE; ISI Alerting Services; Mental Health Abstracts; New Literature on Old Age; PsychINFO; PsychLIT; Psychological Abstracts; PubMed; Social Sciences Citation Index; Social Services Abstracts; Social Work Abstracts; Sociedad Iberoamericana de Información Cientifica (SIIC) Data Bases; SciSearch and ZeitschriftenbibliographieGerontologie (GeroLIT).

\section{Copying}

This journal is registered with the Copyright Clearance Center, 222 Rosewood Drive, Danvers, MA 01923, USA. Organizations in the USA who are also registered with CCC may therefore photocopy material (beyond the limits permitted by sections 107 and 108 of US Copyright Law) subject to payment to CCC of the per-copy fee of $\$ 16.00$. This consent does not extend to multiple copying for promotional purposes. Code 1041-6102/2008. ISI Tear Sheet Service, 3501 Market Street, Philadelphia, PA 19104, USA, is authorized to supply single copies of separate articles for private use only. Organizations authorized by the UK Copyright Licensing Agency may also photocopy material subject to the usual conditions. For all other use, permission should be sought from Cambridge or the American Branch of Cambridge University Press. No other part of this publication may be reproduced, stored or distributed by any means without permission in writing from Cambridge University Press, acting for the copyright holder.

\section{Acknowledgement}

Old Man Crossword, by Louis-Paul St-Onge/iStockphoto; Representative sagittal, transaxial and coronal PiB-PET images overlayed on MRI of a healthy elderly control (left), an age matched subject with mild cognitive impairment (center) and an Alzheimer's disease patient (right) showing different degrees of $A \beta$ accumulation in the brain by $\mathrm{A} /$ ProfVictorVillemagne and Prof Christopher Rowe; A shot of a senior couple practicing tai-chi exercise by Supri Suharjoto/shutterstock 